\title{
A VALLOMÁSOK IGAZSÁGTARTAMÁT MEGHAMISÍTÓK TÍPUSAI ÉS VIZSGÁLATUK KIHALLGATÁSI HELYZETBEN \\ 1. rész, A meghamisító
}

\author{
Czabán Csaba ${ }^{1}$, Alpek Alex² , Bártfai Anna ${ }^{3}$, Kertesy Andrea ${ }^{4}$, Iványuk Áron ${ }^{5}$, \\ Benczúr Lilla ${ }^{6}$, Takács Szabolcs 7 , Kis György ${ }^{8}$ \\ ${ }^{1}$ ANIMA Polygraph Kft, pszichológus, PhD hallgató, \\ 2,3,4,5 Károli Gáspár Református Egyetem, Pszichológia Intézet, hallgató, \\ ${ }^{6}$ klinikai szakpszichológus, \\ ${ }^{7}$ Károli Gáspár Református Egyetem, Pszichológia Intézet, egyetemi adjunktus, \\ ${ }^{8}$ ANIMA Polygraph Kft, Ügyvezető
}

\begin{abstract}
Absztrakt
Cikksorozatunkban annak a kutatómunkának az eredményiről számolunk be, melynek kereteit korábbi cikkünkben bemutattuk (Kis és mtsai, 2017).

Jelen cikkünkben az első hazugságtípusról, a meghamisítóról lesz szó: milyen eltérések mutathatók ki a meghamisítók elbeszéléseinek hanganyagából, mely megkülönbözteti őket más, kihallgatáson részt vett vizsgálati alanyoktól.
\end{abstract}

Kulcsszavak: hazugság • LVA, hangelemzés • tanúvallomás • meghamisítás

A kutatási engedély száma 278/2016/P. A vizsgálatban résztvevő összes vizsgálati alany írásban hozzájárult a hanganyagok és videóanyagok további kutatásokban és tudományos publikációkban való felhasználásához.

\begin{abstract}
We report about the results of a research work in these series of articles, which shares the frame of the researches we have introduced previously. (Kis et al., 2017). In this article we are going to discuss the first figure of the typology of lies: falsifier: certain kind of differences are detectable based on their narratives' voice segments, which defines them as different from the subjects participating at the research.
\end{abstract}

Keywords: lie - LVA - speech analysis - deposition - falsification

Research license 278/2016/P. All participants signed a written document in which they declared: all audio and video records can be used for further researches and academic publications. 


\section{BEVEZETŐ}

A kísérleti kutatások a pszichológiában nem egy esetben laboratóriumi mútermékeket állítanak elő, vagyis nincsen gyakorlati relevanciájuk. ${ }^{1} \mathrm{~A}$ következőkben egy olyan kutatássorozatot fogunk bemutatni, amelyek gyakorlati jelentősége nyilvánvaló. A hazugság jelenségének vizsgálatáról van szó. A szakirodalom részletesen foglalkozik a hazugság alapvető módjaival. Ekman a leplezést (elhallgatás) és a meghamisítást mutatja be (Ekman, 2009), és nem taglalja külön az eltitkoló szerepét. Rámutat arra, hogy a valós kihallgatási helyzetben a hazug eltitkol, leplez, elhallgat, visszatart információkat anélkül, hogy bármi igaztalanságot állítana. A hazug annak érdekében, hogy leplezze magát és elkerülje a büntetést több stratégiát is alkalmaz.

Ahogyan összefoglaló cikkünkben bemutattuk (Kis és társai, 2017): a hazugságkutatók - bár többféle, olykor egymástól jelentősen eltérő megállapításokra jutnak - jórészt egyetértenek abban, hogy hazugságról akkor beszélhetünk, ha:

- a hazugnak szándékában áll a megtévesztést elkövetni, tehát tudatosan igyekszik a valós tényektől eltérő információkat átadni a fogadó félnek;

- a hazug számára tétet jelent e szándék sikerre vitele: vagy valamilyen, számára negatív következményt (pl. büntetést) kerül el vele, vagy pedig közvetlen nyeresége származik a megtévesztésből;

- a hazug tudja, hogy kockázatot vállal megtévesztő cselekedetével.

Kísérleteinkben három hazug típust (meghamisító, elhallgató, titkoló), valamint egy „státusváltó” típust (patetikus) vizsgáltunk. Jelen cikkünk a meghamisító típusra fókuszáló kísérleti eredményekről számol be. Emlékeztetünk arra is, hogy mind a szakirodalom, mind a kísérleti elrendezésünk garantálja, hogy különböző típusokat vizsgálhattunk. Így azt, hogy léteznek különböző hazugság típusok, stratégiák külön nem kell(ett) igazolnunk. Amivel foglalkozunk: tetten érhetők-e a különbözőségek a hangelemzés alkalmazásával - máshol jelennek-e meg eltérések a különböző típusok, stratégiák esetében?

A meghamisítás során a hazug a valós esemény helyett teljesen mást mond el, hamis információt állít be igazként (Ekman, 2009). A hazugnak a meghamisítást alkalmazva állandóan résen kell lennie, hogy a kihallgatás alatt mindig pontosan emlékezzen az általa szőtt hamis történetre. A kognitív erőfeszítés és az érzelmek leplezése nagy terhelést jelent a hazug számára, aminek következménye a szivárgások megjelenése a viselkedésben.

A kutatási összefoglalóban (Kis és mtsai, 2017) részletesen bemutattuk a maffiajátékot, valamint annak szerepeit. A meghamisító típust a maffiajáték során a maffiatagok képviselték. Esetükben az éjszaka való együttmúködés, a nappalok során való, titokban egyeztetett stratégiák kommunikációja jelentette a

Az empirikus megközelítések korlátaira Szummer több közleményében is kitér, hangsúlyozva a relevancia jelentőségét a pszichológiai kutatásokban. (Vö. Szummer 1992; 1993a,b,c; 1994; 2014) 
fő feladatokat. Kellett mindezt úgy tenniük, hogy a város polgárai (a többi vizsgálati személy) ezt ne vegyék észre.

Továbbá a külön instrukciók miatt a kihallgatások során is titkolniuk kellett kilétüket (sőt, a kihallgatást végzőket is át kellett verniük szerepüket illetően). Ez azt jelentette, hogy a kísérlet során feltett kérdésekben (például az éjszakai tevékenységük részletezéséről) folyamatosan „valami mást” kellett mondaniuk, mely a kellően hosszú kihallgatási idő (7-8 perc) alatt komoly megterhelést jelentett számukra.

\section{A MEGHAMISÍTÓ TÍPUSRA VONATKOZÓ HANGELEMZÉSBŐL SZÁRMAZÓ EREDMÉNYEK ISMERTETÉSE}

Jelen cikk a meghamisító, azaz a tényleges „bűnelkövető” /vagy: bűnelkövetővel analóg helyzetben levő személy szerepét járja körül. A bünelkövető esetében lényeges pont a vallomása során a hazugság tényének elrejtése a kihallgató elól. Egy jószándékú tanú estében nem beszélhetünk hazugságokról, bármit is mond a kihallgatáson, az az ő perspektívájából nézve igaznak fog tûnni. Fontos különbséget tennünk tehát a tévedés és a hazugság között. A korábban olvasható meghatározás alapján a hazugság fontos eleme a megtévesztő szándék. Kihallgatás alatt egy bűnös személy az érzelmek rendkívül széles skáláját éli meg. Megélhetik a félelmet (a lebukástól való félelmet), a bủntudatot, de akár az átverés sikeressége által okozott örömöt is (Ekman, 2009; Biland, 2013).

Az eredmények matematikai feldolgozásának alapját lásd e tematikus szám Takács és társai által jegyzett (Takács és mtsai, 2017) cikkében. A típusok öszszehasonlítására egy bootstrap eljárással kombinált varianciaanalízist alkalmaztunk (a bootstrap eljárást más pszichológiai vizsgálatokban is sikeresen lehet alkalmazni, lásd Marcinko et al., 2013). Bár az LVA paraméterekre a normalitás nem teljesült (Kolmogorov-Smirnov tesztet alkalmazva minden változó esetében SIG<0,001 adódott), a bootstrap eljárás segítségével a csoportok közvetlen hibáját határoztuk meg - így a csoportok összehasonlíthatókká váltak egymással (Efron és Gong, 1983). A bootstrap eljáráshoz IBM SPSS 23.0 programcsomagot használtunk.

A normalitás hiánya miatt a varianciaanalízist rangvarianciaanalízis alkalmazásával is ellenőriztük (Kruskal-Wallis tesztet, illetve rang-Welch-próbát), a páros összehasonlításokhoz pedig Bonferroni korrekcióval elvégzett BrunnerMunzel (BM) tesztet végeztünk. A sztochasztikus homogenitás-vizsgálatokhoz (lásd Vargha, 2005) a ROPstat programcsomagot használtuk. Ez utóbbi eredményeit közöljük arra vonatkozóan, hogy mely esetekben, milyen eltéréseket mutatott a többi csoporthoz képest a meghamisító az alábbi okokból:

- a normalitás hiánya indokolttá teszi, hogy rangstatisztikai eszközökkel is vizsgáljuk az eredményeket; 
- a jelen eredmények a hangelemzési eljárás tulajdonosai számára egyéb (üzleti, jelenleg is folyó fejlesztési) okokból szenzitívnek minősíthetők, melyet a sztochasztikus dominancia bemutatása nem sért. Így a tényleges átlagok helyett a dominanciákat fogjuk az eredményeinkben ismertetni.

Megjegyezzük, hogy a sztochasztikus dominancia elnevezés ebben a kontextusban megtévesztő lehet, hiszen a dominancia alapján automatikusan nagyobb értékekre asszociálunk. Itt azonban azt jelenti, hogy jelentős mértékben eltér - akár pozitív, akár negatív irányban - az adott csoport összesített értéke a többi csoportétól. Kiemeljük azt is, hogy az eltérés a történet teljes egészére vonatkozik. Azaz az LVA leírásában található kiemelkedő, extrém értékek egy-egy hangszegmensre vonatkoznak, tehát a történet egészének megítélésére nem alkalmazhatók.

A csoportok közötti eltérések, a nagyságrendi viszonyok így is értelmezhetők maradnak. A Brunner-Munzel-próbát (Bonferroni korrekcióval) kétfajta összehasonlítására is alkalmaztuk. Egyik oldalról a sztochasztikus dominancia (adott csoport mindenki mással összehasonlítva) értékelésére, másik oldalról pedig kizárólag a kontroll csoporttal való összehasonlítására. Az eredményeket egyetlen táblázatban foglaltuk össze, de kétféle módon értelmezzük.

Az első esetben bemutatjuk, hogy mely változók mentén mutathatók ki szignifikáns eltérések (a teljes populációtól, lásd 1. táblázat); a második esetben azt fogjuk vizsgálni, hogy a meghamisítók mely változók esetében nem különíthetők el egy-egy teljes történet elemzésekor a többi csoporttól.

1. táblázat

Tipológiai sajátosságok - sztochasztikus dominancia mértéke az egyes LVA paraméterek² mentén

\begin{tabular}{lccccc}
\hline & Dominancia $^{2}$ & BM & szabadsági fok & p & korrigált p \\
\hline Érzelmi szint & 0,421 & $-4,8$ & 577 & 0 & $0,0000^{* * *}$ \\
Kognitív szint & 0,57 & 4,26 & 574,4 & 0 & $0,0001^{* * *}$ \\
Stressz szint & 0,533 & 1,91 & 528,1 & 0,0565 & 0,2826 \\
Gondolkodási szint & 0,501 & 0,05 & 546,4 & 0,9601 & 1 \\
Közlési hajlandóság hiánya & 0,498 & $-0,13$ & 538,3 & 0,8996 & 1 \\
Koncentráció & 0,561 & 3,76 & 616 & 0,0002 & $0,0009^{* * *}$ \\
Párhuzamos gondolatok & 0,475 & $-1,58$ & 618,2 & 0,1138 & 0,569 \\
\hline
\end{tabular}

${ }_{2}^{2}$ Az LVA paramétereit, annak pontos leírásait a programhasználati kézikönyv részletezi. Összefoglaló cikkünkben (Kis és társai, 2017) ezekből egyeseket ismertetünk, de az összes paraméter teljes ismertetése szétfeszíti egy cikk kereteit (a programhasználati kézikönyv a gyártó oldalán ezeket a paramétereket pontosan részletezi).

3 Amennyiben a dominancia értéke szignifikánsan nagyobb o,5-nél, úgy az adott változóban az adott csoport szignifikánsan magasabb értékeket mutat a teljes populációnál. A szignifikánsan 0,5nél alacsonyabb értékek jelzik az adott csoport populációnál szignifikánsan alacsonyabb értékeit. 


\begin{tabular}{lccccc}
\hline & Dominancia & BM & szabadsági fok & p & korrigált p \\
\hline Egyenletesség & 0,511 & 0,65 & 536,4 & 0,5171 & 1 \\
Zavarodottság & 0,474 & $-1,63$ & 665,3 & 0,1031 & 0,5155 \\
Hazugság stressz & 0,48 & $-1,18$ & 584,7 & 0,2381 & 1 \\
Hazugság valószínűség & 0,465 & $-2,1$ & 565,9 & 0,0359 & 0,1797 \\
Kognitív szint & 0,528 & 1,7 & 582,8 & 0,0888 & 0,4439 \\
Globális stressz & 0,53 & 1,72 & 526,7 & 0,0869 & 0,4343 \\
Téma elutasítottsága & 0,502 & 0,11 & 629,2 & 0,9156 & 1 \\
Reakcióra való várakozás & 0,435 & $-3,95$ & 591,1 & 0,0001 & $0,0004^{* * *}$ \\
Gondolkodási arány & 0,502 & 0,11 & 630,2 & 0,9148 & 1 \\
Tudat alatti megismerési & 0,367 & $-7,79$ & 499,9 & 0 & $0,0000^{* * *}$ \\
szint & 0,539 & 2,39 & 602,7 & 0,0174 & $0,0868+$ \\
Elfojtott érzelmi szint & 0,465 & $-2,08$ & 543,7 & 0,038 & 0,1898 \\
Képzelet, fantázia & & & & & \\
\hline
\end{tabular}

Mindösszesen 5 olyan paraméter van, ahol a történetet meghamisító elkövetők szignifikánsan alacsonyabb vagy magasabb értéket mutatnak, mint bármely más csoport tagjai (nagyon fontos, hogy itt nem minden csoport minden csoporttal kerül összehasonlításra ${ }^{4}$ ).

- Két esetben mutatnak szignifikánsan magasabb értékeket a meghamisítók, mint a többi csoport alanyai:

- Szignifikánsan magasabb a koncentráció szintjük (tehát jobban kell figyelniük arra, hogy mit és hogyan mondanak a releváns, játékra vonatkozó kérdések során).

- Szignifikánsan magasabb (ezzel összhangban) a kognitív erőfeszítések szintje is.

- Három esetben viszont a többiektől eltérő, alacsonyabb értékeket tapasztaltunk:

- Az érzelmi szintjük alacsonyabb (a győzelemhez a játék során hazudniuk kell, ráadásul a „játék” során ók azok, akiket örömmel is tölthet el, hogy nyerésre állnak, hiszen még „életben vannak”), az egész helyzet kevésbé viseli meg őket, mint a többi résztvevőt.

- A kihallgató reakcióira való várakozás szignifikánsan alacsonyabb.

- A tudatalatti megismerési szintjük is alacsony - ők tudják, mi történik, nem gondolkodnak a történteken.

\footnotetext{
4 E folyóiratszám (Takács és társai, 2017) dolgozatában olvashatók az eljárás azon részletei, ahol a csoportok egymással való összehasonlításának eredményei is leírásra kerülnek. Fontos azt is megjegyeznünk, hogy a hivatkozott dolgozatban vizsgáltuk azokat a hatásokat (keresztkorrelációkat és auto-korrelációkat), melyek a csoportok közötti különbségeket befolyásolhatnák.
} 


\section{DISZKUSSZIÓ}

Valós kihallgatási helyzetekben a hazug (valós helyzetben gyanúsított) kihallgatása általában több alkalommal történik meg, folytatólagos kihallgatást végeznek. Az egymást követő kihallgatások között előfordul, hogy több napos szünetek is vannak. A kihallgató jegyzőkönyvben rögzíti a kihallgatást, amit a folytatólagos kihallgatásnál többször is áttanulmányoz. Erre a hazugnak nincs lehetősége, neki az emlékezetét kell segítségül hívnia, ami kognitív erőfeszítéssel jár. Pontosan meg kell tudnia ismételni a korábbi kihallgatásokon elmondottakat, nem szabad ellentmondásokba keverednie. A szervezetét kontroll alatt igyekszik tartani, el akarja fedni azokat az érzelmi jegyeket, nonverbális kommunikációt, ami esetleg a lebuktatásához vezethet. Egy „maszkot” tesz maga elé és meghamisítja az érzelmeit, nem a valós érzelmét mutatja, hanem egy hamis érzelemmel helyettesíti.

Ha egy hazug viselkedése arra utal, hogy megtévesztésről van szó, de anélkül, hogy felfedné az igazság mibenlétét, azt a megtévesztés jelének vehetjük (Ekman, 2009). Márpedig cikksorozatunk videóelemzés részében (Kis és mtsai, 2017) a csatornák elemzésével a verbális tartalom esetében megjelennek azok a jelek, amelyek hazugságra mutatnak, ugyanakkor az LVA is mutat kockázatokat. Az egy további kutatás témaköre lesz, hogy a videó anyagot összeszinkronizáljuk az LVA által másodpercenként jelzett aktuális érzelmi állapot jelzésével. A meghamisító esetében az LVA által jelzett hazugság valószínúsége egyes szegmenseknél alapvonal feletti volt, azonban ez nem volt jellemző a teljes releváns tartalomnál.

A legfontosabb ilyen adat, melyre fel kell hívni a figyelmet, az a hazugság valószínűsége, melyben azt várnánk, hogy ez a csoport szignifikánsan magas értékeket ér el a teljes releváns tartalomban. Idézzük azonban Biland (2013) könyvét, melyben visszatérő momentum az, hogy a megtévesztés öröme is elegendő tétet szolgáltat a hazugság elkövetésére. Az ismertetett kísérleti helyzetben a meghamisítóknál a megtévesztés örömét jól lehetett regisztrálni.

Ha figyelembe vesszük azt, hogy a maffiatagok esetében a játék, a győzelemre való „vágyakozás” - mely megjelenik az érzelmi szint alacsonyabb értékében is, hiszen ők tevőlegesen tehetnek sokat a játék során, kooperatív módon játszhatnak, összedolgozhatnak a többi maffiataggal - éppen azt mutatja, hogy számukra ez a kísérleti helyzet feltehetően élvezetes volt, örömmel töltötte el őket a győzelem esélye (ezt jelezhette az is, hogy éppen az első sikeres „gyilkosság” után avatkoztunk be a játékba, tehát elkezdődött közöttük a sikerrel kecsegtető együttmúködés). A hangelemzés során nyert eredményeket az alábbiak szerint értelmezzük:

A meghamisítókról elmondható:

- Magas kognitív erőfeszítés és koncentráció szint, mely a meghamisításba fektetett mentális feladatok megemelkedett szintjét jelzi. Folyamatosan 
észben kell tartaniuk az elmondottak, „egy alternatív történetet szőnek” a megtörtént események elmondása helyett.

- Az érzelmi szintjük alacsonyabb: az alacsonyabb érzelmi szint abból is eredhet, hogy a játék miatt kevésbé jelentkezett a lebukástól való félelem, ebben az esetben a félelmet inkább a teljesítmény erőfeszítése helyettesítette. Valós bűnügyeknél az érzelmi szint általában magas értéket kap, mert kifejezett a lebukástól való félelem.

- A kihallgató reakcióira való várakozás szignifikánsan alacsonyabb. Általános stratégia a meghamisítók esetében a játék során, hogy lényegében egy előre kigondolt történetet mondanak, „mesélnek” a kihallgatónak.

- A tudatalatti megismerési szintjük is alacsony - ők tudják, mi történik, nem gondolkodnak a történteken. Épp ellenkezőleg: más valamin kénytelenek gondolkodni, más köti le a figyelmüket (visszautalva a magas koncentrációra és kognitív erőfeszítésekre).

Láthatjuk, hogy a meghamisítók esetében a fokozottabb koncentráció és a kognitív szintek magasabb értékei (még a kidolgozott hazugságok esetében is, lásd Littlepage, 1986) árulkodó jelek lehetnek a hangelemzés során.

A játék öröme - illetve az a tény, hogy egy sikeres együttmúködés után kerültek kihallgatásra az alanyok - csökkentette az érzelmi szintjüket, valamint kevésbé figyeltek arra, hogy milyen reakciókat váltanak ki a kihallgatókból.

Összességében arra koncentráltak, hogy a történetet, melyet mesélnek, konzisztensen tudják elmondani. Kognitív erőfeszítéseik és koncentrációjuk lehet az, mely lényegesen megkülönbözteti őket a többi csoporttól (ezek magas szintje), így a leleplezés során ezek azok a jellegzetességek, melyekre érdemes koncentrálnunk. Kutatási eredménynek tekinthetjük a meghamisító esetében, hogy a kapott adatokkal még egyetemi hallgatókkal végzett kísérleti helyzetben is el tudtunk különíteni egy olyan típust, ami a meghamisítóra jellemző tipológiát viseli. Az éles valós helyzetekben vizsgált és befejezett ügyek visszajelzéseinél 95\% arányban lehetett elkülöníteni a kapott tipológiákat.

\section{KITEKINTÉS, ÖSSZEFOGLALÁS}

Elmondható, hogy a szakirodalomban több ponton is megemlített stratégia, miszerint egyetlen csatornára érdemes fokozott figyelmet fordítani a hazugság felderítése és tettenérése során, sikeres irány lehet e kísérlet során is (DePaolo és mtsai, 1982; Zuckerman és mtsai, 1982). Azt azonban ki kell hangsúlyoznunk, hogy ezekben az esetekben „itt és most” tettenérési stratégiákról beszélünk.

Fontos tudnunk azt, hogy kísérletünk folytatásában a hangelemzést kiegészítettük HD minőségű videófelvételekkel is, melyek segítségével több csatorna egyidejü vizsgálata is lehetővé válik (Kis és mtsai, 2017e). Ezek a vizsgálatok 
viszont rögzített felvételek elemzését jelentik (hang- és videófelvételekét egyaránt), tehát nem „itt és most” stratégiájú tettenérésről van szó!

Ki kell emelnünk azt is, hogy a kísérlet második fázisában egyes csoportokban nem vártunk az első sikeres gyilkosságig, így a meghamisítók esetében a „sikeres együttmúködés” adta öröm nem jelent meg a kihallgatások során. Ugyanakkor azoknál a meghamisítóknál, akik „átestek” a gyilkosságon, mutatkozott az öröm, mint a megtévesztés jele. ${ }^{5}$

E dolgozatban ismertetett, hangelemzésből származó eredmények az egyik tartóoszlopát képezik azon munka első fázisának, melyet e folyóirat jelen számának hasábjain igyekszünk bemutatni. Az ANIMA cégcsoport és a NEMESYSCO vállalat a Károli Gáspár Református Egyetem Pszichológiai Intézetének Hazugságkutató múhelyével közös kutatásának eredményei tehát a szakirodalommal összhangban lévő eredményeket hoztak - de teljesen más megközelítést alkalmaztak. Továbbá a hazugsághoz kapcsolódó új nonverbális jeleket (Kis és mtsai, 2107e) sikerült azonosítani, melyeket az LVA hangelemző technológiának is köszönhetünk.

$\mathrm{Az}$ „itt és most” tettenérés stratégia helyett teljes történetek, tipológiák feltárását tűztük ki célul - mely cél eléréséhez tartó út első eredményeit, a meghamisítóra vonatkozó, hangelemzésből származó egyedi eredményeket mutattuk be dolgozatunkban.

Világos számunkra, hogy egyetlen tipológia esetében a 20 különböző paraméterből mindösszesen 4-5 esetében találtunk a meghamisító és más típusok között eltérést. A számos paraméter mentén nem feltétlenül mutat ez első ránézésre jelentős differenciáló hatást. Vegyük azonban figyelembe: 3 alap tipológia esetében kimutatott eltérések összessége viszont elegendő hatást tud kiváltani ahhoz, hogy egymástól jelentős mértékủ eltéréseket mutassanak. Hiszen, ha minden típus esetében csak 4-5 eltérést detektálni tudunk, az összességében 12-15 olyan pont, ahol markáns differenciáló hatást jelent, melyek segítségével lényegesen precízebb csoportosítások hozhatók létre. Külön kiemeljük azt, hogy miután páronként is összehasonlítottuk a csoportokat, itt minden esetben úgy kerültek kialakításra a fontosabb paraméterek, hogy elmondhattuk: minden kialakított tipológia eltért egymástól (hiszen ezeknek a tényezőknek volt jelentős, differenciáló hatása).

\footnotetext{
5 Erre azért volt szükség, mert az első felvételek készítésekor és eredményeinek értékelésekor minden esetben vártunk az első sikeres együttmúködésig - így nem tudtuk tesztelni, hogy enélkül is tetten érhetők-e jellegzetességek a meghamisítók esetében? Vizsgálataink további fázisaiban ezekre a kérdésekre is szeretnénk válaszokat kapni.
} 


\section{BIBLIOGRÁFIA}

Biland, C. (2013). A hazugság pszichológiája. Budapest: Háttér Kiadó.

DePaulo, B. M., Lassiter, G. D., Stone, J. L. (1982). Attention determinant of success at detecting deception and truth. Personality and Social Psychology Bulletin, Vol. 8 (2), 273-279.

Efron, B \& Gong, G. (1983). A Leisurely Look at the Bootstrap, the Jackknife, and Cross-Validation. The American Statistician, Vol. 37 (1), 36-48.

Ekman, P. (2009). Beszédes hazugságok. Budapest: Kelly Kiadó Kft.

Littlepage,G. E., Tang, D.W., Pineault, M. A. (1986). Nonverbal and content factors in the detection of deception in planned and spontaneous communications. Journal of Social Behaviour and Personality, Vol. 1(3), 439-450.

Marcinko, D., Jaksic, N., Ivezic, E., Skocic, M., Surányi, Zs., Loncar, M., Francic, T., Jakovljevic, M. (2013): Pathological Narcissism and Depressive Symptoms in Psychiatric Outpatients: Mediating Role of Dysfunctional Attitudes, Journal of Clinical Psychology, 70(4), 341-352.

Szummer Csaba (1992): Szent György harca a Hermeneutika Sárkányával avagy mitől féltsük és mitől ne a pszichoanalízist. Pszichológia (12) 3: 43-51.

Szummer Csaba (1993a): Hermeneutikai fordulat előtt a pszichológia? Pszichológia (13) 4: 579-580. Szummer Csaba (1993b): Temészettudomány-e a pszichológia? Pszichológia (13) 4: 399-402.

Szummer Csaba (1993c): Freud nyelvjátéka. A pszichoanalizis mint hermeneutika és narráció. Bp., Cserépfalvi - MTA Pszichológiai Intézete.

Szummer Csaba (1994): Tertium non datur. - Válasz Pléh Csaba cikkére. Pszichoterápia, 1994/4. Szummer Csaba (2014): Freud, avagy a modernitás mítosza. KGRE - L’Harmattan Kiadó, Bp., Vargha A. (2005). Sokaságok összehasonlítása új módszerekkel. Statisztikai Szemle 83, 429-448. Zuckerman, M., Amidon, M. D., Bishop, S. E., Pomerantz, S. D. (1982). Face and tone of voice in the communication of deception. Journal of Personality and Social Psychology, Vol. 43 (2), 347-357.

\section{Tematikus szám hivatkozott cikkei}

Kis Gy., Takács Sz., Liberman, A.; Benczúr L. (2017). A megtévesztés tipológiája - összefoglaló tanulmány. Psychologia Hungarica Caroliensis, 4(2), 2016. pp. 7-26.

Takács Sz., Kis Gy., Makrai B., Liberman, A. (2017). Tipológiákhoz tartozás varianciaanalízis alkalmazásával, LVA hangelemzés vertikális vizsgálata. Psychologia Hungarica Caroliensis, 4(2), 2016. pp. 79-93.

Kis Gy., Füzes N., Mátay G., Pusker M., Makrai B., Czabán Cs., Takács Sz. (2017e). Újfajta szivárgások leírása a vallomások során, videófelvételek elemzésével. Psychologia Hungarica Caroliensis, 4(2), 2016. pp. 60-78. 